\title{
泉浴および飲泉の家鬼腸管筋電図におよぼす影響
}

\author{
東北大学医学部 第一外科学教室 \\ (主任 櫝 哲夫教授) \\ 東北大学医学部 温泉医学研究施設 \\ (施設長 杉山 尚教授)
}

安田真—

\section{THE EFFECTS OF HOT-SPRING BATH AND ORAL INTAKE OF HOT-SPRING ON THE ELECTROMYOGRAM OF THE RABBIT INTESTINE}

\author{
Shinichi YASUDA \\ Department of Surgery, Tohoku University School of Medicine \\ (Director : Prof. T. Maki) \\ and \\ Institute of Balneology, Tohoku University School of Medicine
}

(Director: Prof. T. Sugiyama)

Hot-spring bath, dry heat bath, instilation of hot-spring, plain 45 rabwater and 5\% saline solution into the duodenum were tried in the total of bits and the effect of these preparations on the motility of small and large intestines were studied by the use of electromyography. The hotsprings used in the present study were of Narugo Branch Hospital and of Narugo National Hospital.

The results obtained are summarized as follows :

1) In the group of rabbits with hot-spring bath preparation, both the duration of each spike-bursts and the interval between the adjoining two sets of spike-bursts prolonged as long as $\mathbf{3 0}$ minutes after bathing.

On the other hand, dry heat bath $\left(41^{\circ} \mathrm{C}\right)$ resulted in the reduction of both duration and interval of the spike-bursts during and immediately after the dry heat bath and gradually they tended to return to the control levels in 10 minutes. In these experiments, electromyograms taken from the small and large intestines were almost the same in findings.

It is concluded that the both hot-spring bath and dry heat bath lead to the excitement of intestinal motor function and the former has the stronger effect than the latter. The dry heat bath elicites an increase in the motor function of the intestines during and immediately after the dry heat bath, while the hot-spring bath causes an increase in the intestinal motility lasting approximately 30 minutes. These findings may have some relationship to the chill or warm sensation after bathing.

2) Instilation of the hot-spring, either of Narugo Branch Hospital or of Narugo National Hospital, plain water and five per cent saline solution at the temperature of between $40^{\circ} \sim 41^{\circ} \mathrm{C}$ into the duodenum failed to cause any noticeable changes of electromyographic findings such as of duration or interval of the spike-bursts. Therefore, it was learned that the instilation of these four kinds of solution had little effect on the motor function of the duodenum.

Out of these findings, it is estimated that the hot-spring bath which increases the motor function of the intestines has a considerable significance in its clinical application. Oral administration of the hot-spring, however, seems to have little effect on the motor function of the duodenum. 
はじめに

古くより各種の疾患に対して温泉療法が行なわれて来 たが，温泉の作用因子，作用方式に関する従来の知見は 経験医学的なものであって，てれらが現代医学の姐上に 上ったのは比較的最近のととと云える. しかも消化器疾 患に対する泉浴の利用が民間において比較的多いにもか かわらず，従来の研究は飲泉作用，とくにその含有成分 の薬効学的特異作用に関心が向けられ，泉浴時の消化器 機能に関しては研究業績が少ない，泉浴と胃分泌機能 に関する研究はかなりの数にのばるが๋1-3)，胃腸の運動 機能に関しては極めて少なく，レ線学的観察 ${ }^{4-7) ~ お よ ひ ゙ ~}$ 胃運動曲線描写法 ${ }^{4-6)}$ を用いての胃運動機能に関する研
究，あるいは剔出腸管に対する温泉成分の影響，などが 散見されるのみである．また飲泉療法においても，飲泉 と胃分泌機能に関する研究 ${ }^{8-10)}$ は多いが，飲泉と胃腸 運動機能に関する研究は比較的少ない.

著者は家鬼 45 羽について，平滑筋々電困法を用いて， 泉浴が大腸および小腸運動におよばす影響を熱気浴と比 較して観察した。.また温泉水を十二指腸に注入した場合 における十二指腸の運動については淡水および食塩水注 入時と比較して検討した。 その結果 2,3 の興味ある知見 を得たので報告する。

\section{実 験 方 法}

実験動物として 体重 2 3kg の健康成熟家鬼 45 羽を 用いた。

筋電図の導出には三栄測器製 UB204 型笳電計を, 記 録には CO-2 型ブラウン管連続撮影装置を用いた。電 極としては直径 $0.3 \mathrm{~mm}$ の銅線を塩化銀でメッキし，1 $\mathrm{mm}$ の間隔で固定した双極電極を用いた。室温は $30^{\circ} \mathrm{C}$ から $32^{\circ} \mathrm{C}$ の間に保つようにした。

泉浴の大腸および小腸筋電図におよばす影響について は，家兔 25 羽を用い，熱気浴群 12 羽（大腸 6 羽，小腸 6 羽), 泉浴群 13 羽 (大腸 6 羽, 小腸 7 羽) の 2 群に分 けて比較観察した。

泉浴には第 1 表に示す様な泉質の鳴子分院の源泉を用 い，泉浴および熱気浴の温度を $41^{\circ} \mathrm{C}$ とし，入浴時間を 5 分間とした. 筋電図は浴前, 浴中, 浴直後, 10 分後, 20 分後, 30 分後と時間を追って導出した.

家鬼は家験開始前 12 時間絶食とし, ウレタン $0.3 \mathrm{~g} / \mathrm{kg}$ 皮下注射で麻酔を行ない，正中切開にて開腹した。つい で電極を盲腸端より 10 20cm 肚門側の大腸膨隆部わよ び回腸末端より 30 〜0 $\mathrm{cm}$ 口側の小腸の漿膜面に刺入固 定し，開腹した・腹壁の縫合創部にはコロジオンおよび ワゼリンを二重に塗布し防水の完全を期した。

飲泉の十二指腸筋電図におよばす影響については, 家 兔 20 羽を用い, 淡水注入群 5 羽, $0.5 \%$ 食塩水注入群 5 羽, 国立鳴子病院源泉注入群 5 羽, および鳴子分院源泉 注入群 5 羽の 4 群に分け各群の成績を比較した。

家鬼を 12 時間絶食せしめ, ウレタン $0.3 \mathrm{~g} / \mathrm{kg}$ 皮下注 射して麻酔を行ない開腹, 双極電極を幽門より 15〜20 $\mathrm{cm}$ の十二指腸漿膜面に刺入固定した。別に胃に小切開
表 1. 鳴子分院源泉主成分

$\begin{array}{lc} & \text { 含芒硝食塩泉 } \\ \mathrm{Na} & 710 \\ \mathrm{Ca} & 38 \\ \mathrm{Cl}^{\prime \prime} & 567 \\ \mathrm{SO}_{4}, & 658 \\ & \quad \mathrm{mg} / \mathrm{kg}\end{array}$

表 2. 国立鳴子分院源泉主成分

\begin{tabular}{|c|c|}
\hline \multicolumn{2}{|c|}{ 芒硝泉 } \\
\hline $\mathrm{Na}$. & 210 \\
\hline $\mathrm{Ca}$. & 150 \\
\hline $\mathrm{Cl}^{\prime}$ & 60 \\
\hline $\mathrm{SO}_{4}{ }^{\prime \prime}$ & 560 \\
\hline
\end{tabular}

を加え，ととより 4 号 Nélaton カテーテルを約 $5 \mathrm{~cm}+$ 二指腸に挿入し閉腹した. カテーテルはビューレットに 連結し，十二指腸への注入速度を一定に出来るようにし た.ついで $40^{\circ} \mathrm{C} \sim 41^{\circ} \mathrm{C}$ の鳴子分院の源泉 (表 1 ), 国 立鳴子病院の源泉（表 2 ）, $0.5 \%$ 食塩水および淡水を, それぞれの群について 6〜10cc カテーテルより 2〜3 分 をかけて注入し, 注入前, 注入直後, 5 分後, 10 分後, 20 分後および 30 分後の筋電図を描記した.

筋電図所見の検討にはスパイク群持続時間およびスパ イク群間隔を示標とした。
A. 泉浴の大腸および小腸筋電図におよぼす影響につい $\tau$
1. 大腸筋電図

各群における各例の筋電図所見は類似の傾向を示した 


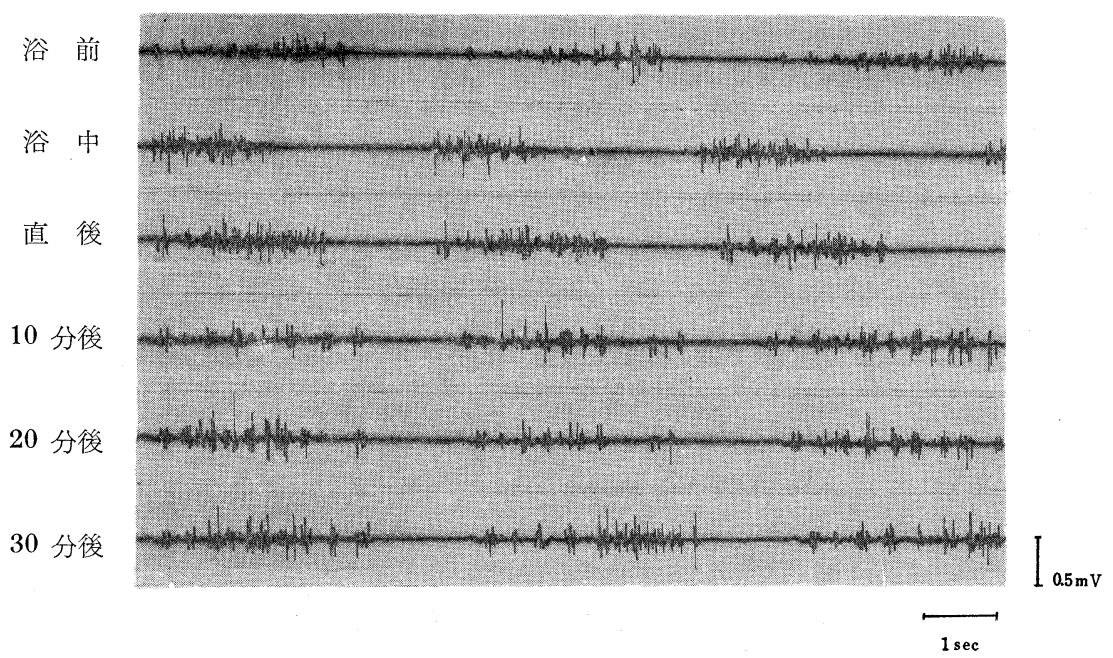

図 1 熱気浴時の大腸筋電図

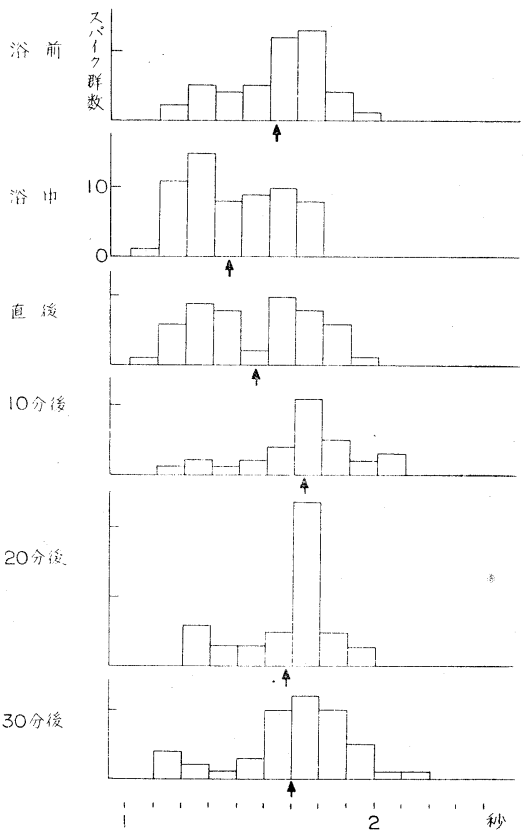

図 2 A. 大腸，熱気浴群におけるスパイク群持続時間

ので代表的 1 例につき図示説明する.

a. 熱気浴群

まずスパイク群持続時間についてみると，図1および 図 $2 \mathrm{~A}$ に示す様に浴前には平均 1.62 秒であったが, 浴 中では平均 1.46 秒と短縮し, 浴直後では平均 1.53 秒と なり浴中の值よりやや延長したが，浴前にくらべると短 縮していた. 10 分後, 20 分後および 30 分後ではそれ

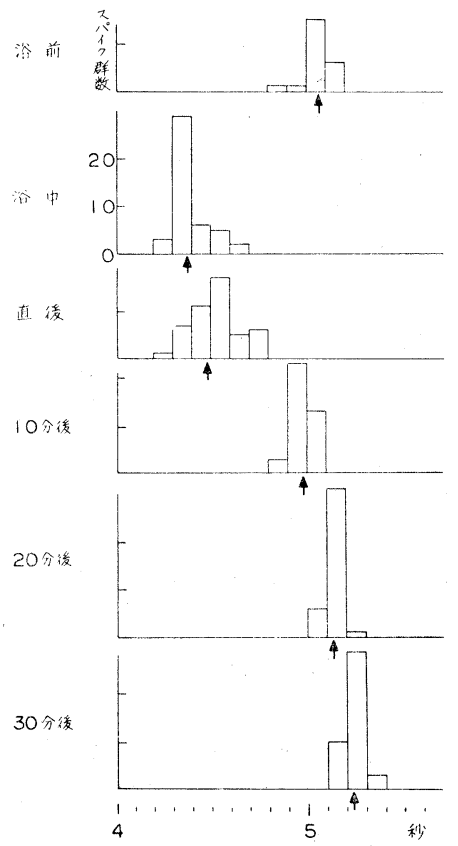

図 2 B. 大腸, 熱気浴群におけるスパイク群間隔

ぞれ平均 $1.73 ， 1.65 ， 1.69$ 秒となり浴前值に近似した. スパイク群間隔についても，持続時間とほぼ同様の傾 向を示し，図 1 および図 $2 \mathrm{~B}$ の如く，浴前には平均 5.04 秒であったが，浴中では平均 4.37 秒、浴直後では平均 4.51 秒となり浴前にくらべ短縮した. 浴後 10 分, 20 分 および 30 分ではそれぞれ平均 4.96，5.12，5.23 秒とな り浴前に近似した。 


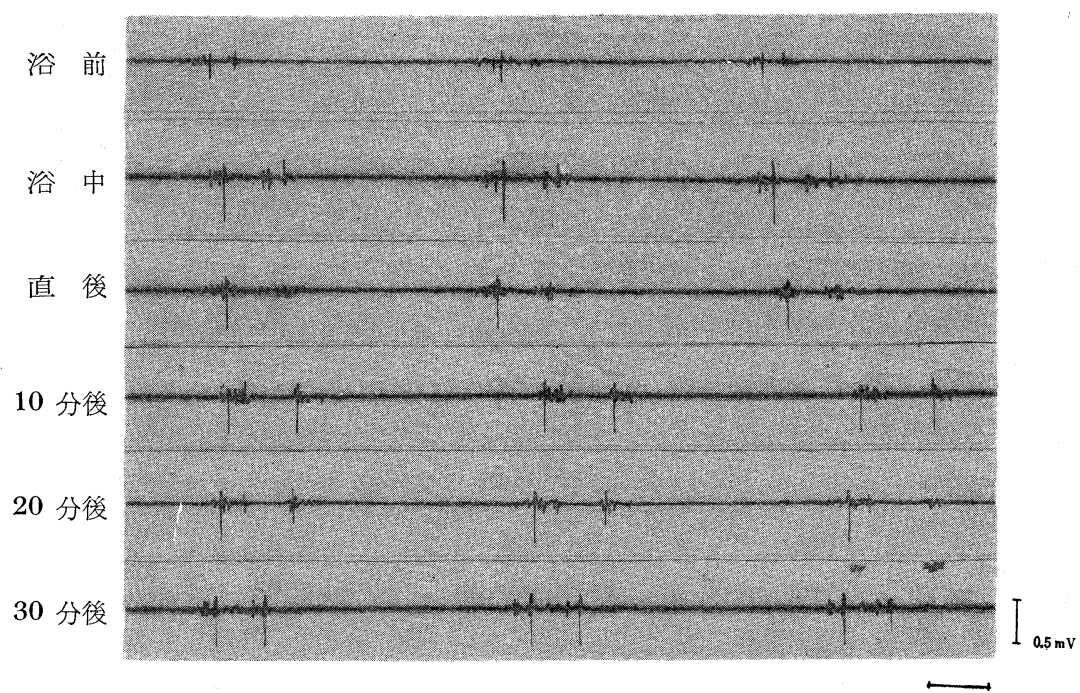

図2 泉浴時の大腸筋電図

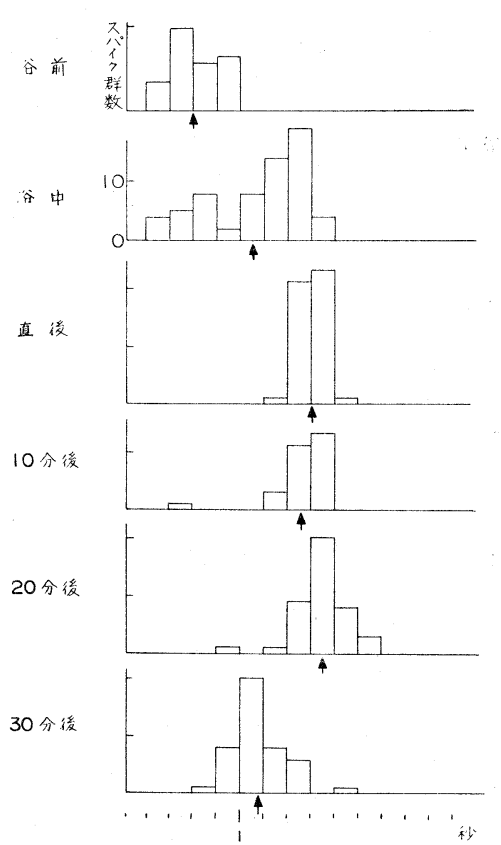

困 4 A. 大腸，泉浴群におけるスパイク群持続時間

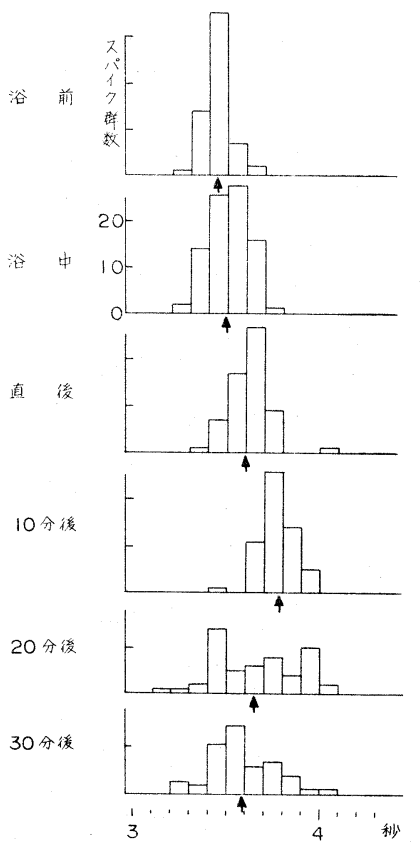

図 4 B. 大腸，泉浴群におけるスパイク群間隔
すなわち，熱気浴群においては，持続時間および群間 隔は，浴中より浴直後にかけて短縮し，10 分後にはは ぼ浴前に回復する傾向がみられ，熱気浴により浴中から 浴直後にかけて，大腸の運動が軽度に六進するてとが考 えられる。

b. 泉浴群

スパイク群持続時間については，図 3 および図 $4 \mathrm{~A} の$
如く，浴前の平均值は 0.80 秒であったが，浴中では平 均 1.05 秒と延長し, 浴直後, 10 分後および 20 分後で はそれぞれ平均 $1.29 ， 1.05 ， 1.34$ 秒となり，浴前にくら べ，さらに延長の傾向を示した．しかし 30 分後では平 均 1.08 秒となり 20 分後にくらべ短縮し，浴前值に回 復する傾向を示した。

またスパイク群間隔についてみると，図 3 および図 
$4 \mathrm{~B}$ の如く, 浴前の平均 3.43 秒に対し, 浴中では平均 3.49 秒となり, 明らかな延長を示さなかったが, 浴直後 および 10 分後では, それぞれ平均 $3.60,3.77$ 秒と時間 の経過と共に軽度の延長を示した. 20 分後および 30 分 後では平均 $3.64,3.53$ 秒となり, 次第に浴前值に近似 短縮する傾向がみられた。

泉浴群の大腸笳電図では, 持続時間および群間隔に共 に延長し, 持続時間は 30 分後においても浴前にくらべな お延長の傾向を示すととがわかった。ててのてとから泉浴 により大腸機能が軽度に六進されるてとが考えられる。

以上のととから熱気浴と泉浴の大腸運動機能に及ぼす 影響を比較すると，熱気浴群ではスパイク群の持続時間 および間隔が短縮し，泉浴群では延長の傾向を示すとと から, 泉浴群においては熱気浴群にくらべると大腸運動 の興奮の程度は大であり，またその興奮性の持続も長い ととが考えられる.

2. 小腸筋電図

各群における各例の筋電図所見ははぼ類似の傾向を示 したので代表例につき図示説明する.

\section{a. 熱気浴群}

まずスパイク群の持続時間についてみると, 図 $5 \mathrm{~A} の$ 如く, 浴前には平均 0.84 秒を示した. 浴中, 浴直後, 10 分後, 20 分後および 30 分後にはそれぞれ平均 0.78 , $0.74 ， 0.73 ， 0.76 ， 0.86$ 秒となり浴前にくらべ明らかな 変化をみなかった。

スパイク群間隔は図 5B の如く, 浴前には平均 3.53 秒 を示した．浴中には平均 2.83 秒で浴前にくらべ短縮し， 浴直後には平均 2.79 秒となり,さらに短縮を示したが, 浴後 10 分, 20 分にはそれぞれ 平均 3.03 秒, 3.16 秒と なり時間の経過と共に回復の傾向をみせた。 そして 30 分後には平均 3.03 秒となり浴前值にほぼ復帰した.

以上の結果より熱気浴群においては浴中から浴後にか けて群間隔は短縮し，30 分後にはほぼ浴前に 回復する ととがわかった。とのととから熱気浴により家鬼小腸の 運動が軽度ながら光進するととが考えられる。

b. 泉浴群

スパイク群持続時間についてみると，図 $6 \mathrm{~A}$ の如く, 浴前平均值は 0.54 秒であり，浴中および浴直後では， それぞれ $0.68,0.64$ 秒となり浴前にくらべ明らかな延 長を示さなかった. 10 分後, 20 分後では, それぞれ平 均 $0.84,0.95$ 秒となり延長を示した. 30 分後では 0.72 秒となり浴前の值に復䏒する傾向を示した。

スパイク群間隔についてみると, 図 $6 \mathrm{~B}$ の如く, 浴前 の平均值 2.97 秒に刘し, 浴中, 浴直後にはそれぞれ平 均 3.16, 3.12 秒となり浴前にくらべ明らかな延長がみ られなかった. しかし 10 分後, 20 分後および 30 分後 では，それぞれ平均 $3.27 ， 3.48 ， 3.50$ 秒となり時間の経

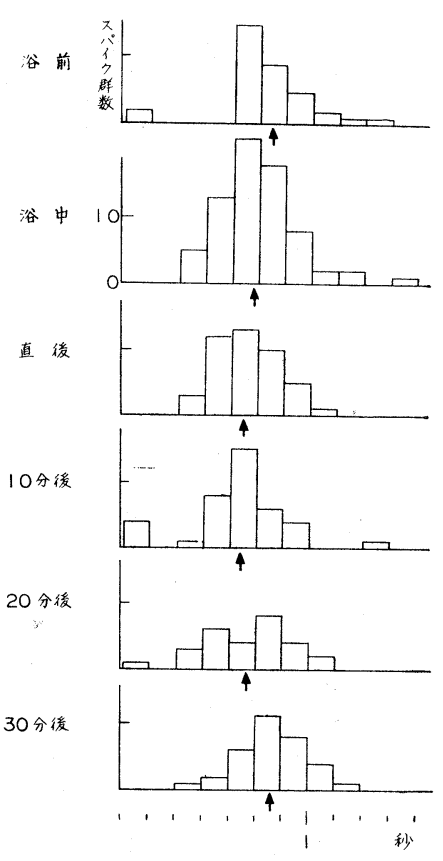

図 5 A. 小腸, 熱気浴群におけるスパイク群持続時間： ‘

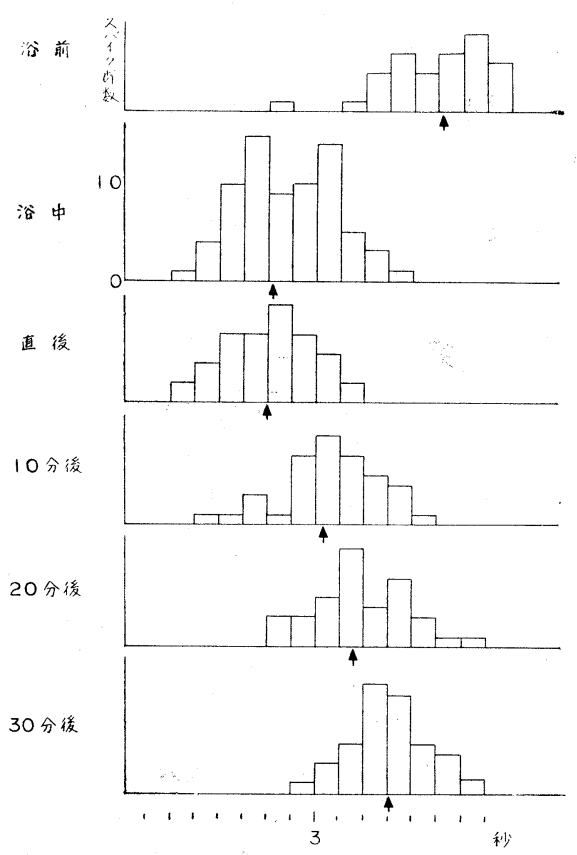

四 5 B. 小，腸熱気浴群におけるスパイク群間㼨

過と共に延長する傾向を示した。

すなわち，泉浴群においては，持続時間および群間隔 共に 10 分後より 延長し 30 分後においてもなお延長の 態度を示すととが明らかとなった。てのととは泉浴によ り小腸の運動機能が軽度にえ進されるととを示すものと 


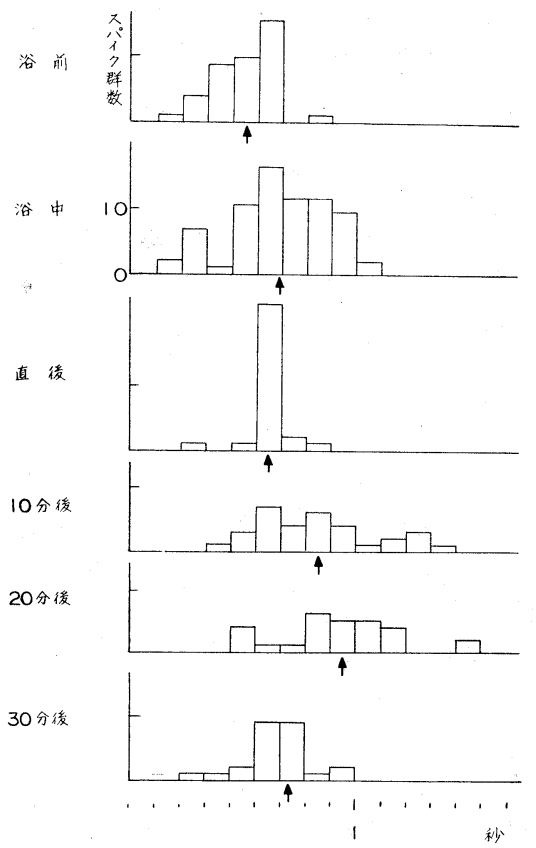

図 6 A. 腸泉, 浴群におけるスパイク群持続時間

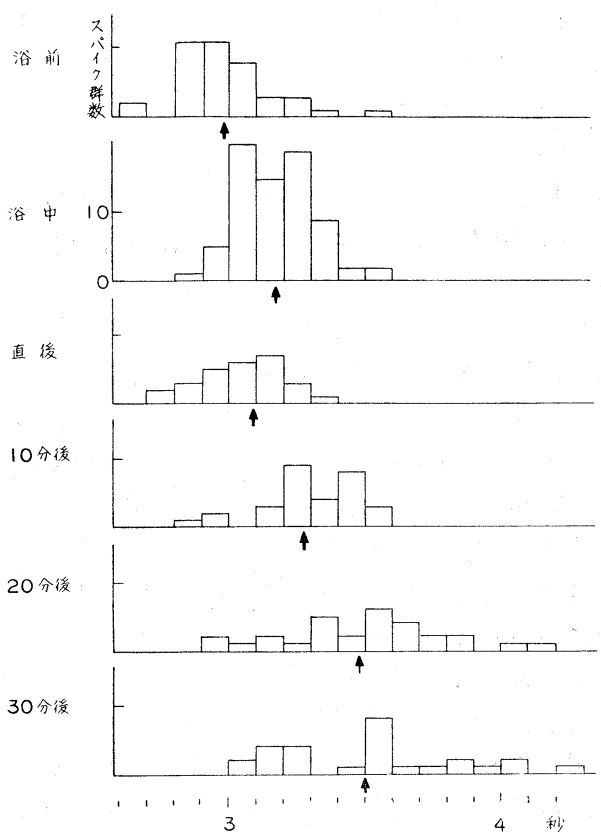

図 6 B. 小腸泉浴群におけるスパイク群間隔

思われる。

以上のととから，泉浴は大腸におけると同様に，熱気 浴にくらべ家鬼小腸の運動に対し 比較的強い影響を与 え，かつその作用は熱気浴にくらべると長く持続するて とが推察される。

\section{B． 领泉の十二指腸筋電図におよほす影響について}

各群における筋電図のスパイク群持続時間および間隔 は類似の傾向を示したので各群における平均值を示すて とにする。

1. 淡水注入群

スパイク群の持続時間をみると，注入前には平均 1.06 秒であったが、注入直後，5 分，10 分，20 分および 30 分後には，それぞれ平均 $1.00,0.98,0.91,0.83,0.80$ 秒を示したが，明らかな短縮という変化はみられなかっ た.

スパイク 群間隔は 注入前には平均 2.79 秒を示し，注 入直後, 5 分, 10 分, 20 分および 30 分後は平均 2.88 , $2.88 ， 2.86 ， 2.81 ， 2.78$ 秒となり，注入前にくらべると 明らかな延長の態度とはいえなかった。

2. $0.5 \%$ 食塩水注入群

スパイク群持続時間は注入前の平均值 0.63 秒に対し, 注入直後, 5 分後, 10 分後ではそれぞれ平均 $0.68,0.66$, 0.66 秒とわずかに 延長の 傾向をみせ，20 分後では平均 0.57 秒と短縮し， 30 分後では平均 0.64 秒を示したが， これらの変化は明らかな短縮，延長の態度とはいえない と思われる.

スパイク群間隔は，注入前には平均 2.76 秒であった が，注入直後， 5 分後とも平均 2.76 秒を示し，注入前 にくらべ変化がみられず，10 分後， 20 分後および 30 分 後では，それぞれ平均 $2.71 ， 2.73 ， 2.71$ 秒となり注入前 にくらべ短縮したが，ての数值上の短縮はでく僅かで短 縮の変化とはい光ない所見であった。

3. 国立鳴子病院源泉注入群

まずスパイク群の持続時間についてみると，注入前に は平均 0.73 秒を示したが，注入直後，5 分， 10 分， 20 分後および 30 分後では，それぞれ平均 $0.89 ， 0.90$, $0.84 ， 0.84 ， 0.88$ 秒を示し 注入前とくらべ延長を 来し た.しかしてれらの延長の数值はでく僅少で，延長の態 度とは考えられない。

スパイク群間隔は注入前には平均 2.64 秒を示し, 注 入直後, 5 分, 10 分, 20 分および 30 分後にはそれぞれ 平均 $2.69,2.76,2.78,2.79,2.82$ 秒となり 延長を示し たが，とれは僅少の延長で明らかな延長の態度とは考元 にくい.

4. 鳴子分院源泉注入群

スパイク群の 持続時間は 注入前には平均 0.75 秒で, 注入直後, 5 分, 10 分, 20 分および 30 分後ではそれぞ れ平均 $0.79,0.83 ， 0.89 ， 0.84 ， 0.88$ 秒となり 注入前に くらべ僅かな延長を来した。

スパイク群間隔は 注入前は平均 2.74 秒であったが， 注入直後, 5 分後ではそれぞれ平均 $2.72,2.73$ 秒となり 注入前にくらべわづかに短縮をみた。 10 分， 20 分およ 
び 30 分後ではそれぞれ平均 $2.78,2 \cdot 85,2.87$ 秒となり わづかに延長した。

スパイク群の持続時間の延長，間隔の短縮および延長 は何れも極く僅少の変化で，乙れをもって明らかな延長 あるいは短縮の態度とはいえない。

以上の実験成績より考えると， $0.5 \%$ 食塩水注入では 十二指腸の運動にはとんど影響はなく，また淡水の十二 指腸注入によっては持続時間が僅かに短縮するがスパイ

最近平滑筋々電図法の発展に伴ない，胃のみならず腸 管各部の活動電位が容易に導出記録出来るようになり, 消化管運動機能の研究は飛躍的な発展をとげた。しかし 消化管運動機能に対する泉浴の影響を電気生理学的にと らえた報告は著者の知るかぎりでは見当らない。

そこで著者は泉浴および飲泉の腸管運動におよばす影 響を腸管筋電図から追求してみたのであるが，飲泉の影 響は明らかでなく，泉浴による運動機能の克進は軽度で あったししたかって本論文においては変化が明らかであ ったスパイク群の持続時間および間隔から腸管の運動機 能を論ぜざるを得なかった，筋電図におけるスパイク放 電の持続時間と間隔については，一般に蠕動運動の軽度 の六進時には放電間隔および持続時間がかとなりより 強い克進時には放電間隔および持続時間が大となると云 われている11,12). そてでしれに準拠して実験成績を分析 した.

泉浴と消化管運動機能に関する研究は極めて少ない が，末岡4)はヒト胃の運動機能におよばす温泉浴の影響 を $42^{\circ} \mathrm{C} 5$ 分間の泉浴を行ってレ線学的ならびに胃曲線 描写法によって観察し, 泉浴時には一般に胃運動が元進 し, 特に浴後 30 分前後において著明であり, 胃内容排 出時間は著明に短縮すると述べている．また杉山占，宇 野6) らもヒト胃についてレ線透視および胃運動曲線描写. 法によって胃運動に対する泉浴の影響を観察している. それによれば一回泉浴によりレ線上胃の排出速度, 蠕動 周期は一般に促進するものが多いが，他の少数では明ら かに遅延するといい，また胃運動曲線による観察でも同 様であって，一回泉浴により一般に胃運動は強盛になる ものが多いが，減弱するものも可成りみられ，一定の影 響は示さない.乙れは泉浴刺激をうける個体の当初の運 動機能の如何によるものと考えられ, 従って胃運動機能 におよぼす泉浴の影響に関する研究は一回泉浴の影響を 云々するよりも，連泉浴クールの影響を検討するととに 大きい意味があると報告している．著者の実験において は，泉浴によって，筋電困上スパイク群持続時間および 間隔は浴中より延長し, 浴後 20 分ないし 30 分で延長度 は最も著明であった。とれは泉浴によって腸管の運動は
ク群隔にははとんど変化がみられないので十二指腸運動 には変化がないものと考えられる。また国立鳴子病院, 鳴子分院両源泉の注入ではともにスパイク群持続時間, 群隔いずれもやや延長し，十二指腸運動の元進が推定さ れるが，しかしその程度はそれ程著明ではなく，またそ の内容を分析すれば個体差もかなりあるので, 温泉注入 によって一律に運動の克進をきたすと推定するととは困 難である。

\section{按}

六進され, しかも 30 分後においても運動の 京進が持続 するものと考えられた。ただし著者の実験は家鬼腸管に ついて行われたものであり，ただちにヒト胃についての 成績と比較するととは出来ないが，本実験の結果は末岡 の成績とはぼ一致するものと考えられる.

さらに腸管運動に対する泉浴の影響を明らかにするた めに本実験では家鬼に熱気浴を行ない泉浴群と比較し た. 熱気浴は, 臨床上外科領域において腸管麻痺の保存 的療法として腸管の蠕動六進を目的としてしばしば用い られている13)。 また笳電図学的に温度の上昇は平滑笳の 運動機能を充進させ低温は低下させるといわれている. 本実験においても熱気浴は家鬼腸管の運動を元進させる ことが明らかにされた。しかし泉浴群と比較すると，前 者においてはスパイク群持続時閒および間隔の短縮, 後 者においては延長という筋電図上明らかに異なる興奮態 度を示した。このととから泉浴は腸管運動に対し，ほぼ 同じ条件下の熱気浴より強い影響を与えるものと考えら れる.

これらのととから泉浴の腸管運動立進作用は熱気浴の 作用と比較するととによっても明らかにされよう。

また筋電図上の興奮所見は，熱気浴においては浴中， 浴直後に明らかであったのに対し，泉浴においては浴後 $10,20 ， 30$ 分時に明らかであった。てれらの所見は温 水浴後に起る湯ざめ感, 泉浴後に起るほとぼり感に関係 があるのではないかとも考えられ興味深い. 湯ざめ感の 発生については浴後の発汗，あるいは皮膚血管の拡張に より熱幅射が立進して体温を失なう傾向が強くなること が考えられているが，熱気浴の場合にも温水浴と類似の 現象が起るのではないかと考えられる.はとばり感の発 生に関しては，温泉が末梢血管挔張性物質を含むとと， また含有成分によっては浴後皮膚に附着して気化熱の発 散を防ぐてとなどによると考えられている ${ }^{14,15)}$.

また増田16) らは古くからいわれているいわゆる、熱 の湯ミあるいはミあたたまりの湯ミの存否について，胃 内温度の面から検討している，それによれば一般に胃内 温度は入浴中より上昇し, 出浴後も上昇を続けるととが 多く, 淡水浴では浴後 30 分で浴前值に復帰するのに泉 
浴においては 30 分後もなお浴前値より上昇しており， かつ泉質により差があると述べている。

以上のととから泉浴の腸管運動機能におよぼす影響を 考察すると, 温度による作用は淡水浴と異なる所はない と思われるが，淡水浴にくらべ興奮作用が強く，浴直後 よりむしろ 15〜30 分後にその興奮が強いというととは 淡水と異なった泉質に原因を求めざるを得ないである う。こう考元ると泉質によって興奮作用などに，ある程 度の違いが生じ得るととは增田の報告にもある様に当然 考朰られる所である。しかし胃運動に対して泉質間の差 異は認められないという杉山17) の報告もあるので，乙 の点についてはなお検討を要しょう。

また泉浴は熱気浴にくらべ，腸管運動を光進させ，そ の持続も比較的長いととを考えると, 術後腸管機能の減 退, 不整に対しても泉浴が効果的に㗢らくてとが考えら れ，創傷治療の促進，消化吸収機能の賦活などと相まっ て, 泉浴の治療学的応用は広沉多面的であることを痛感 した.

つぎに飲泉と消化器運動機能に関して従来の報告をみ ると, Hirsch ${ }^{18)}$ は七トについて，含土類食塩泉である Mordorfer 鉱泉を混じたバリウム栯を投与しレ線透視 により観察を行ない，その小腸通過が促進されるととを 明らかにした。杉山占は は上トついて硫酸塩泉が胃排出 速度および胃蠕動周期共に促進するといっている。また 日野19) は，ヒトについて含炭酸重曹食塩泉である磯部 鉱泉を飲用させた場合の胃および小腸のレ線観察を行な い, 胃については，その原液（食塩の濃度約 $2 \%$ ）を用 いた場合，運動機能は低下し，2 倍稀勫液では克進を示 すが，小腸では原液および 2 倍稀釈液のいずれも運動を 促進すると述べている．日野は，乙れは同鉱泉に相当高 濃度に含まれている食塩の影響によるものであろうと考 え, さらに各種濃度の食塩水を飲用した場合について観 察し，胃の運動は低張液 $(0.1 \%, 0.5 \%)$ で克進し，高 張液（3\%，4\%）で低下するが，小腸運動機能は，低張 あるいは等張液では変化を認めないが高張液では克進す るといっている. 著者の実験においては食塩水および温 泉水注入のいづれも，十二指腸運動に著明な変化を与え なかったが，食塩水の濃度が $0.5 \%$ であるとと，および

\section{む}

家鬼 45 羽について, 平滑筋々電図法を用いて温泉 浴（鳴子分院源泉）の大腸および小腸運動機能におよば す影響を熱気浴群と比較して検討した。また，それとと もに，鳴子分院源泉，国立鳴子病院源泉を十二指腸に注 入した時の十二指腸運動機能におよぼす影響を，淡水注 入および $0.5 \%$ 食塩水注入と対比して観察しつぎの結果 を得た。
著者の用いた国立病院源泉および鳴子分院源泉は共に食 塩を含むが約 $0.07 \%$ と極めて 稀薄微量な低張液である ととを考えると, 日野の報告とほぼ一致するものと考元 られる。

胃腸の機能に対する温泉飲用の作用因子としては, 温 度, 量などの非特異的作用および含有成分の化学的作用 などがあげられるが，Pfeiffer ${ }^{20)}$ は胃腸運動機能は温泉 の化学的成分によるよりも, その滲透圧に左右されると とが多いと述べている. Meyer, Schütz ${ }^{21)}$ 食塩水の 腸運動機能におよばす影響について, 低張および等張液 は腸運動機能に影響を与えず，高張液は蠕動を克進させ しかも濃度の高いものはどその影響が大きいと述べてい る. また硫酸ナトリウムについて Latkowski22) は濃度 が少である時は腸運動機能に対して方進作用はないと述 べている.

また温泉の含有成分の化学作用については, ほとんど が動物の剔出腸管の墏膜面に対する影響をみたものであ り, 粘膜面からの作用と同一険ずるととは出来ないと 考えられるが，主な塩類について二三の成績をあげる と, 食塩については, 斎藤 $\left.{ }^{23}\right)$ は高濃度 (30\%) のもの はど腸管に対する興奮性が強く，1\%，0.1\% 溶液では変 化を認めなかったといっている。 また坂根24) は剔出腸 管に対し，2\%，5\%，20\%の食塩水を作用せしめると， $2 \%$ の場合は腸運動を亢進せしめるが，5\%においては 抑制し，20\%においては腸管運動を全く停止すると述 べている．また田中25) は剔出猫胃について炭酸塩の作 用を検討し $0.06 \sim 0.15 \%$ では促進的に，それ以上の濃 度では抑制的に作用すると述べている，その他各種の塩 類イオンの影響について多くの報告があるが，温泉は極 めて稀薄微量の塩類が多数混在し, 個々の塩類の影響の みならず塩類相互の相乗作用あるいは拮抗作用などを考 えると一層複雑な作用を有するものと考えられる.

杉山は飲泉作用についても泉浴作用と同様に温度, 滲 透圧，含有成分の化学的作用のほかに，綜合刺激による 非特異的生体変調作用を考えなければならないと述べて いるが，乙れら種々の作用因子相互の影響に関してはま だ不明の点が多く今後の研究に待たねばならない。

び

1）泉浴群および熱気浴群における大腸筋電図所見と 小腸筋電図所見はほぼ類似し，泉浴群においてはスパイ ク群の持続時間および 群間隔がともに延長し，浴後 30 分にも延長の所見が見られたが，熱気浴群においては持 続時間あるいは間隔が浴中より浴直後にかけて短縮し， 10 分後には浴前に回復する傾向が見られた。との筋電 図所見から泉浴および熱気浴は腸管の運動機能を六進さ 
せるが，泉浴による興奮は熱気浴による興奮とくらべる とより強いものと思われる。また熱気浴にて起る腸管 の運動機能の克進は浴中から浴直後に見られるのに対 し，泉浴の場合には浴中から浴後 30 分頃まで見られる と考えられる。とれは湯ざめの現象あるいは浴後のほと ばり感に関係するのではないかと推察される.

2）鳴子分院源泉，国立鳴子病院源泉、淡水，および $0.5 \%$ 食塩水を十二指腸に 注入して，飲泉による筋電図 の変化を検討したが，スパイク群の持続時間および間隔

\section{文}

1) Jaworski, W. : Klinische-experimentelle Untersuchngen über die Wirkung des Karlsbader Thermalwasser auf die Magendarmfunktion. Dtsch. Arch. Klin. Med., 37, $1,1885$.

2）菅井正憲, 大内多門： 湯の平温泉における 習慣 浴法,「掛讨湯」の胃液分泌機転に及泟寸影響. 臨 床の日本，10，1234，1942.

3) 宇野嘉一郎：温泉と胃機能に関する臨床的研究. 第 2 報, 温泉々胃分泌機能. 日本温泉気候学会雑 誌, 25, 76, 1961.

4) 末岡 繁： 温泉浴の 胃運動機能に及壮す影響に 関する臨床的研究. 臨床と研労, 23, 237, 1946.

5) 杉山 尚, 岡崎太郎 : 消化器と温泉. 診断と治 療, 46, 1571, 1956.

6) 宇野嘉一郎：温泉と胃機能に関する臨床的研究. 第 1 報温泉浴と胃運動機能. 日本温泉気候学会雑 誌, 25, 60, 1961 .

7) Weskott, H. : Der Einflu $\beta$ des AachenBurtscheider Mineralwassers auf die Sekretion und Motilität der Magens beim gesunden und kranken Menschen. Zschr. ges. exper. Med., 32, 307, 1923.

8) Penzoldt,F. : Die Wirkung der Kohlensäure auf die Magenverdauung. Dtsch. Arch. klin. Med., 73, 200, 1902.

9) 山形敞一：秋田県大湯温泉に於汀る療養相談所 調查成績, 特にその 2,3 温泉学的作用について. 東北医学雑誌, 32, 39, 1943.

10) Bickel,A.: Experimentelle Untersuchungen über den Einfluß der Mineralwässer auf die sekretorische Magenfunktion. Berl. Klin. Wschr., 43, 42, 1906.

11）㟪 哲夫，鈴木泰三：平滑筋及電図の 基礎と 臨 床, 144 頁, 金原出版社, 東京, 1966 .

12) Iwamatsu, T. : Electromyographic observation of intestinal movement during intes-
の面からみれば $0.5 \%$ 食塩水, 淡水注入では殆んど変 化を示さないが，両源泉注入では持続時間および間隔と もに僅かながら延長がみられた。したがって温泉注入に よって十二指腸の運動六進が推定されるがその変化は必 ずしも明確なものでない.

以上のととから，少なくとも泉浴は筋電図学的にも腸 管の運動機能をえ進させるととが確認されたので，その 臨床的応用は大いに検討さるべきであうう。

\section{献}

tinal obstruction. Tohoku J. exp. Med., 84, 282, 1964.

13）高山坦三：外科と物理療法. 日本外科全書, 6 巻, II, 32 頁, 金原出版社, 東京.

14) 杉山 尚: 温泉医学 1. 現代内科学大系, 17 巻, 40 頁, 中山書店, 東京, 1959.

15）富田雅雄：浴湯後の「ホトボリ」の感について. 日本温泉気候学会雑誌，3，245，1943.

16) Masuda, H. \& Ohara, M. : Studies on the temperature of the gastrointestinal tract, 2nd report. Influence of bathing on the intragastric temperature. Tohoku J.exp. Med., 54, 363, 1951.

17）杉山 尚：温泉と二・三消化機能に関する研究. 日本温泉気候学会雑誌，19，134，1955.

18) Hirsch, S. : Röntgenologische Untersuchungen zur Trage der Einwirkung von Minesalsalzen und natürlichen Wasser auf die Darmmotiliät. I. Ueber die Wirkung sogenannter abführender Wasser. Zschr. ges. exper. Med., 32, 307, 1923.

19）日野 衛：磯部鉱泉並に袋田温泉飲用の胃腸運 動機能に及浔す影響. 日本温泉気候学会䧱誌， 17, 87, 1953.

20) Pfeiffer, T. : Üeber die Resorption wässeriger Salzlösungen aus dem menschlichen Magen. Arch. exp. Path. u. Pharm, 48, 437, 1902.

21) Meyer, H. u. Schütz, J. : Pharmakologie der Mineralwässer. Handbuch der Baln. med. Klim. u. Balneogr., Bd. II, p 136, Leipzig, 1922.

22) Latkowski, J. : Über den Einfluß des Marienbader Wassers auf die motorische und sekretorische Tätigkeit des Magens. Wien. klin. Wschr., 12, 706, 1899.

23) 斎藤幾久次郎：塩原温泉並にその温泉成分の 消 化管に及はす影響について. 日本温泉気候学会雑 
誌，20，191，1957.

24）坂根弥三次：高張食塩水静脈内注射の小腸運動 に及汸す影響に関する実験的研究・京都府立医科
大学雑誌, 11, 425, 1940.

25）田中研一：孷酸含有泉の剔出全胃運動に及ぽす 影響. 医学研究, 11, 3021, 1943.

(1966 年 9 月 1 日 受付) 